\title{
Health and Economic Implications of Waste Dumpsites in Cities: The Case of Lagos, Nigeria
}

\author{
Ogunrinola, I. Oluranti (Corresponding author) \\ Department of Economics, Covenant University, Ota, Ogun State, Nigeria \\ E-mail: olu.ogunrinola@covenantuniversity.edu.ng \\ Adepegba, E. Omosalewa (Miss) \\ Department of Economics, Covenant University, Ota, Ogun State, Nigeria \\ E-mail: justshally@yahoo.com
}

\author{
Received: January 14, 2012 \\ Accepted: March 10, 2011 \\ Published: April 1, 2012 \\ doi:10.5539/ijef.v4n4p239 \\ URL: http://dx.doi.org/10.5539/ijef.v4n4p239
}

\begin{abstract}
Refuse dumpsites are found both within and on the outskirts of cities in Nigeria and due to poor and ineffective management, the dumpsites turn to sources of health hazards to people living in the vicinity of such dumps. This study was designed to examine the health and economic implications of solid waste disposal among sampled residents of two major refuse disposal dumps in Lagos, Nigeria. The data used for the study were generated from primary source, while SPSS software was used in the data analyses. In addition to the descriptive analysis which forms the bedrock for the conclusion drawn in this paper, both linear probability and ordinary least squares regression models were also used in the analyses. The models examined the determinants of health status as well as the labour supply of the sampled respondents respectively. The results show that pollution variables are statistically significant in the determination of health status as well as the labour supply performance of respondents. Based on these findings, policy measures that would enhance the health status and improved labour market performance of residents were proposed.
\end{abstract}

Keywords: Waste management, Landfills, Dumpsites, Labour market, Environmental pollution

JEL Classification: I18, J24.

\section{Introduction}

The cities of third world countries are growing at very rapid rates compared to those in the developed nations. For instance, a UN-Habitat report observed that Africa is the fastest urbanizing continent having cities like Cairo, Lagos, Nairobi, Kinshasa among others growing at fast rates that would make them triple their current sizes by the year 2050 (UN-Habitat, 2010). Such high rate of growth of cities has implications for the provision of urban infrastructural services to prevent the proliferation of urban slum. The increasing growth of cities, therefore, has implications for municipal waste management among other social services required in the urban communities. Data from many of the cities shows inadequacy in urban social services like shelter, provision of safe drinking water and efficient management of solid wastes. The cities are therefore littered with 'mountains' of rubbish in landfills and open (in most cases illegal) waste dumps which are covered with flies and thus serve as breeding grounds for rodents and mosquitoes which are carriers of diseases.

In a bid to examine the link between environmental pollution arising from waste dumps and public health, the United Nations Environmental Programme (UNEP) conducted a pilot study of the Dandora Waste Dump in Kenya. The study, as tentative as it was, showed that a link exists between the two. The extensive tests carried out on the soil and water around the dump site in comparison with samples from other sites as well as medical tests carried out on humans living around the dumpsite shows evidence of infections from water, land and air pollution. The leachates generated in the landfills and open dumpsites are sources of pollution which is inimical to public health (UNEP, undated). The conclusion from this and other studies has led to an increasing interest of researchers in the studies relating to several aspects of municipal solid waste management in urban cities of many nations (Yongsi, et al, 2008; Boadi and Kuitunen, 2005; Aluko and Sridhar 2005; Nwanta 2010; Aatamila et. al. 2010, among others). Many of the researchers who have undertaken studies in the area of environmental pollution are mainly from the 
natural sciences who are interested in studying the nature and the chemical properties of environmental pollution, as well as its effects on plants and animals (e.g. Yongsi et.al, 2008). Though some studies conducted by social scientists have examined the social consequences of the present urban waste management issues, yet, few of these studies examined the health implications of people living in close proximity of waste dumpsites (Sarkhel, 2006; Yongsi et. al 2008; Abul, 2010; Babatunde and Biala, 2010, Nabegu 2010, Nwanta et. al. 2010). The main objective of this study is therefore to examine the health effect of living around solid waste dumpsites in Lagos Nigeria, as well as the economic effects of living in such filthy environment. The rest of this paper is organized as follows: Following this introductory section, we discuss the Theoretical Framework and Literature Review in Section two. Section three discusses the Methodology of Study while Section four gives the interpretation of data. Section five concludes the study.

\section{Theoretical Framework and Brief Survey of Literature}

\subsection{Theoretical Framework}

Many studies on waste management and its implications for the city dwellers take their theoretical root in the conventional wisdom regarding the trade-off between industrial growth and income inequality among the citizenry. Given that high level of savings is a pre-requisite for investment and rapid growth, Kaldor (1978) believes that an income distribution skewed towards the entrepreneurial class, who are believed to be having high marginal propensity to save, is good for growth. On the other hand, Kuznets (1955) and Lewis (1954) are of the view that rapid industrial progress in the modern urban sector triggers labour transfer from the low productivity sector to the cities, giving rise to high initial aggregate increase in inequality which will later decrease (Kaldor, 1978; Kuznets, 1955). However, this conventional wisdom has not gone unchallenged in the literature given recent data from cross-country studies as clearly articulated by Birdsall, Ross and Sabot (1995), among others.

The Kuznets' hypothesis has been adapted by scholars in the environmental studies to explain the relationship between the growth in income per capita and various indicators of environmental degradation, and it is popularly referred to as Environmental Kuznets Curve (EKC). The main argument of EKC is that the level of environmental degradation (as a result of pollution from industrial and domestic activities) first rises, gets to a peak and later declines as income per head increases in the economy. The EKC proposition was brought into prominence by the World Bank in 1992 which argued that "as incomes rise, the demand for improvement in environmental quality will increase, as will the resources available for investment" (IBRD, 1992; p.39). Following the World Bank's study, Grossman and Krueger (1995) estimated an econometric model where the level of pollution per capita was made a quadratic function of real GDP using a panel regression approach. The pollution variables used are the quality of water and ambient air in cities worldwide. The resulting scatter plot of pollution-income relationships appear as an inverted U-shape, but with the peaks of predicted pollution-income paths varying across pollutants but in most cases they come before a country reaches per capita income of $\$ 8,000$ in 1985 dollars (Grossman \& Krueger, 1995, p. 353).

A number of intellectual debates centering on the critical survey of the EKC proposition in the literature have been published. As widely surveyed by Stern (2003), criticisms of EKC have been on both theoretical and methodological grounds as shown by the works of Arrows et al (1995), Stern et. al (1996) and Stern, 1998. Following these, recent modifications to the EKC model have introduced additional explanatory variables such as political freedom, output structure, and trade openness, among others. These modifications led to a revised EKC curve which did not significantly alter the inverted U-shaped curve but shifts its position downwards and to the left due to technological change (Stern, 2003, p.12). The identified weaknesses of EKC hypothesis notwithstanding, evidence abound in the literature that the level of solid waste generation and the resulting environmental pollution is high in developing countries of Africa, Asia and Latin America as compared to the developed nations. This can be linked to the rural-urban migration and urbanisation phenomena as well as externality effect of solid waste generation in production and consumption activities as the economy develops industrially.

Economic theory has posited a strong link between economic growth and the growth of cities. Thus, there is a positive relationship between urbanization and income per capita. For instance in 2009, a UN-Habitat's report put the proportion of African population living in cities at $40 \%$ (395 million), but by 2050, urban population projection would have increased to $60 \%$ rising to 1.23 billion persons (UN-Habitat, 2010). The report is of the view that rapid growth of cities is neither good nor bad in itself unless such rapid growth results in urban congestion, slum and increase in environmental pollution from increased solid domestic and industrial waste generation that is not adequately managed. Since, most developing nations in the wake of urbanization and industrialization are still grappling with the problem of adequate management of solid waste being generated, this study represents an attempt to determine the health and economic implications of waste dumps in the city of Lagos. 
Waste dumps or landfills are generally safely constructed to minimise any form of negative externality, (e.g. pollution of ground water via leaching) to the surrounding areas. According to Environmental Research Foundation (2011); " $A$ secure landfill is a carefully engineered depression in the ground (or built on top of the ground, resembling a football stadium) into which wastes are put. The aim is to avoid any hydraulic [water-related] connection between the wastes and the surrounding environment, particularly groundwater. Basically, a landfill is a bathtub in the ground; a double-lined landfill is one bathtub inside another." Three types of landfills are normally used for solid waste disposal and they are: secured or sanitary landfills, controlled landfills and open dumps. As defined above, secured or sanitary landfills are highly lined at the base to prevent infiltration by percolating liquids, controlled landfills are waste dumps where the refuse are merely covered with soil, and in open dumps there is no standard for refuse dumping (Gouveia and do Prado, 2010).

In developing nations, a great proportion of solid waste generated are dumped either in controlled landfills or open dumps which constitute sources of health risks to surrounding residents. The use of sanitary landfills is not feasible for many waste management authorities of most countries due to cost constraints. In their study of health risks of urban solid waste landfill sites in Sao Paulo, Gouveia \& do Prado discovered that in Brazil; only $47 \%$ of all the garbage collected were disposed of in sanitary landfills, $23 \%$ in controlled landfills while the remaining $30 \%$ were in open dumps. For Manzini city in Swaziland, Abul (2010) confirmed that open dumpsites rather than secured landfills are more in number for waste disposal and this constitutes great health hazards to the residents. Such open dumps are found on the outskirts of urban areas which form breeding sites for disease-carrying vectors in the communities. The cost issue has prompted some municipal government authorities in some developing nations to adopt cost-reduction programme as well as conservation tenets of "reduce, reuse, and recycle" to reduce the level of waste generation and recycle others, whether bio-degradable or non-biodegradable items. This is being achieved through aggressive community education of consumers and producers on waste reduction methods, while institutions and businesses that could buy up discarded materials are facilitated to enhance recycling and reuse. These activities not only have positive environmental impact on the communities involved, but also have an important economic dimension (Goldman and Ogishi, 2001).

The preponderance of open dumps in many developing nations has spurred the need to examine the health implications of such dumps to the surrounding residents. For instance, Yongsi et. al. (2008) conducted a cross-sectional epidemiological study to examine the health risks of different waste disposal system in Cameroun. The study found a $14 \%$ diarrheic prevalence among the respondents and a strong statistical association was found between household refuse management methods and incidence of diarrhea among the respondents. Salam Abul (2010) examined the health impact of solid waste management among residents around the Mangwaneni Dumpsite in Swaziland. The study is unique in that the respondents were stratified by the distance of their homes to the dumpsite. The first group are those having their homes within 200 metres radius, while the second group live from 200 metres and beyond from the Manzini Dumpsite in Swaziland. The study, which was conducted among 78 households found a negative relationship between the distance of residential apartments from dumpsite and being affected by the dumpsite pollution. This study has adopted similar approach towards the determination of health, economic and labour supply implications of living around waste dump sites in Nigeria.

Studies relating to the health status and its labour market implications for residents around waste dump sites in Nigeria are few. The studies by Babatunde and Biala (2010) and Yahaya et. al. (2011) only examined the externality arising from production and consumption of sachet water in Kwara State while Yahaya et al (2011) made an attempt to determine the contamination level and the distribution of pathogenic substances in well water located near the municipal solid and liquid wastes in Zaria, Northern Nigeria. Since there appears to be a unanimity in literature that improper waste management and indiscriminate littering of the environment are linked to diseases arising from air, land, water and environmental pollution (IBRD, 1999), it is thus imperative to examine the magnitude of the impact of such health effects on those living in close proximity with pollution sources. This study is an attempt to fill this yawning gap.

\section{Methodology}

\subsection{Research Design}

This study covered two waste dumpsites in Lagos State of Nigeria. The study is aimed at measuring the socio-economic consequences of living around the waste dump sites and how such effects might impact the labour market performances of such individuals. To enable us do this, two dump sites were purposefully chosen: the Olusosun dumpsite which is the largest transfer loading station managed by the Lagos State Waste Management Agency (LAWMA), and an open dumpsite along Oke-Afa carnal which started as an illegal open dump. Preliminary mapping activities were carried out to delineate the survey areas. Three areas were delineated: residential houses 
within two hundred and fifty metres $(<250$ metres) radius; residential houses within 250 metres to less than 500 metres ( 250 to $<500$ metres) and areas within 500 metres but not more than 750 metres ( 500 to $\leq 750$ meres) radius from the dumpsite. Each of the three areas is designated as LOC1, LOC2 and LOC3, beginning from the area closest to the dumpsite.

The data collection exercise employed a structured questionnaire which was administered by trained enumerators in each of the designated areas around the two dumpsites. The random sampling approach was used in the selection of the respondents from each of the LOC1, LOC2 and LOC3 around the two refuse dumps. A total number of 100 households was intended to be sampled with the proviso that only the household members who are fifteen years and above are qualified to be interviewed. The structured questionnaire was divided into five sections:

- The first section addresses the issue of pollution from the dumpsite

- The second addresses health issues

- The third addresses the economic impact of pollution using income as its indicator

- The fourth addresses the measures put in place either by the community or the Government to control pollution.

- The fifth addresses household characteristics of respondents, while

- The sixth is the bio-data of the respondent.

At the end of the survey exercise, a total number of 72 households, made of one hundred and ninety-eight individuals were interviewed giving a response rate of 72 per cent.

\subsection{The Models, the Data and Analytical Technique}

Two basic models are postulated and estimated.

Model 1: The main economic model in this study is the health production function from which we go ahead to determine, empirically, the factors responsible for the state of health of the $i^{\text {th }}$ individual in the survey area. The health status of the individual is therefore posited to be a function of various factors. Some of these include environmental factors around the dumpsite, education, income level, employment status, among others. The health production function is represented by the following equation, following Grossman (1972) and Pedrick (2001):

$$
H=f(E N V, L O C, L M C, H H S, P C)
$$

Where:

$\mathrm{H}=$ the self-reported health status of the respondent and this is measured in two ways, $\mathrm{H}_{1}$ and $\mathrm{H}_{2} . \mathrm{H}_{1}$ is a binary variable which takes value 1 if the respondent rarely/never falls ill within the reference period prior to the survey and zero if he/she sometimes/always falls ill. On the other hand, $\mathrm{H}_{2}$ measures the state of illness of the respondent measured with the value of zero through 3 , where zero is equivalent to being in excellent health and three in bad health. ENV = Environmental factors affecting the health of the individual. Such factors include BRN=burning, $\mathrm{ODR}=$ Odour, distance as measured by $\mathrm{LOC}(=\mathrm{LOC} 1, \mathrm{LOC} 2$ and $\mathrm{LOC} 3$ as previously defined $) . \mathrm{LMC}=\mathrm{Labour}$ market characteristics of the individual respondent which are: EMPS=Employment status, whether employed (EMP) or unemployed (UEMP); EMPN=Nature of employment whether wage (WG) or self-employed (SLF), EARN=Earnings per month, Labour market experience (EXP) and educational attainment of the respondent $($ EDUC). HHS = Household status of the respondent whether head (HD), or non-head (NHD); GHD = Gender of the household head whether female (GHF) of male, (GHM) and residential status whether tenant (TNT) or owner $(\mathrm{OWN}) . \mathrm{PC}=$ Personal characteristics of the respondent which include age (AGE), gender (GND), marital status (MRT), among others.

Therefore, re-writing equation (1) above we have:

$$
\begin{gathered}
H_{i}=\alpha_{0}+\alpha_{1} O D R+\alpha_{2} B R N+\alpha_{3} L O C+\alpha_{4} E M P+\alpha_{5} S L F+\alpha_{6} E A R N+\alpha_{7} E X P+\alpha_{8} E D U+\alpha_{9} H D+ \\
\alpha_{10} G H M+\alpha_{11} O W N+\alpha_{12} E X P^{2}+\alpha_{13} G N D+\alpha_{14} M R T+\mu_{k}
\end{gathered}
$$

Note that $\mathrm{H}_{\mathrm{i}}=\mathrm{H}_{1}$ or $\mathrm{H}_{2}$ as earlier defined above.

In the estimation of equation (2) when $\mathrm{H}_{1}$ is used as the dependent variable, the method of estimation adopted is the linear probability model (Gujarati, 2009; Pindyck and Rubinfeld 1981) while the ordinary least squares method is used when $\mathrm{H}_{2}$ is the dependent variable.

Model 2: The second model postulated in this study relates to the analysis of the factors affecting the income level of the respondents given the dumpsite environment in which they live and where some also work. This is based on the human capital model as specified by Garry Becker (1975) and Jacob Mincer (1974). Using the log of earnings as 
the dependent variable, equation (3) below is specified to examine the impact of environmental pollution variable, in addition to other traditional variables, on the distribution of income of respondents. The equation is specified as:

$$
\begin{aligned}
L O G E A R N & =\beta_{0}+\beta_{1} O D R+\beta_{2} B R N+\alpha_{3} L O C+\beta_{4} E M P+\beta_{5} S L F+\beta_{6} E X P+\beta_{7} E D U+\beta_{8} H D+\beta_{9} G H M \\
& +\beta_{10} O W N+\beta_{11} E M P+\mu_{k}
\end{aligned}
$$

\section{Data Analysis and Discussion of Results}

\subsection{Brief Description of the Sampled Dumpsites}

Two dumpsites were selected for this study. The first dumpsite known as the Olusosun dumpsite is located at Ojota area of Lagos and it covers an area of about 42 hectares of land (Aderibigbe, 2010). The dumpsite, which is claimed to be the largest landfill in Lagos covers areas around Ikosi Ketu, Oregun industrial estates, the commercial area of Kudirat Abiola way, and Ojota residential area. The dumpsite is being managed by the Lagos State Waste Management Authority (LAWMA). The dumpsite is said to be the repository of more than $50 \%$ of about 9,000 metric tonnes of solid waste generated in the Lagos Metropolis on a daily basis.

The second dumpsite from where data was collected for this study is the Oke-Afa dumpsite which is located at the T-junction that leads to Ejigbo, in the Lagos Metropolis. The dumpsite is very close to the Isolo general hospital, the Isolo market, while there are residential areas around the dumpsite. The area, known as Oke-Afa is a community in the Oshodi-Isolo Local Government/Ejigbo Local Council Development Area, which came into the limelight on two occasions. The first was the time a military plane crashed into the canal in 1992, killing 45 military officers on board; and in January 2002 when there was an explosion from the Ikeja cantonment. The rush of panicking multitudes trying to escape from the bomb explosion area led to the death of many residents of Oke-Afa area in the canal located in the area (Apata, 2011). Being a smaller and illegal dumpsite, Oke-Afa is not as active as Olusosun dump which is being managed by LAWMA, a government-owned Agency in Lagos State. The site is however, still being used (illegally), and the areas around the dump are surrounded by residential houses while scavengers eke out some existence on and around the dumpsite.

\subsection{Socio Economic Characteristics of the Respondents}

The result of data analysis shows that $48 \%$ of our respondents are female while the remaining $52 \%$ are male. In terms of age, none of the respondents was less than 16 years of age and the highest percentage of respondents are between the age cohorts of 26-35 years. Other age groups in the survey are those in the 16-25 years category which represent $33 \%$, the $36-45$ years age group followed next at $23.2 \%$ while those above 46 years are $13.6 \%$. In terms of marital status, many of the respondents are married (49\%), those that are single constitute $45 \%$ while the rest are either divorced $(5 \%)$ or separated $(1 \%)$. In terms of formal educational attainment, only $1.5 \%$ of them never attended formal educational institutions. Those who have up to secondary education are about $34 \%$, while those with post-secondary education are $64 \%$.

Sixty-four percent of the respondents are employed and are thus engaged in various labour market activities in the urban labour market of Lagos. In terms of the type of employment engaged in, 33\% of those employed are in self-employment while the remaining $67 \%$ are employees. With respect to income level, out of the one hundred and fifty nine that responded to the question on average monthly earnings, $21 \%$ earn less than $\$ 15,000,34 \%$ earn between $\$ 15,000$ - $\mathrm{N} 28,999 ; 35 \%$ earn between $\$ 30,000$ and a little less than $\$ 45,000$, the remaining $11 \%$ earn $\$ 45,000$ and above. Note that US $\$ 1=\$ 150$ at the time of the survey.

\subsection{Waste Dumpsites, Environmental Pollution and Health Status of Respondents}

\subsubsection{Environmental Pollution and Health Status of Respondents}

In many developing nations, dumpsites serve several purposes in addition to being a place to deposit domestic, medical and industrial wastes. For many urban poor, dump sites are places of work for waste pickers, waste collectors using push-cart to dump refuse on waste sites, waste buyers who sell them to recyclers and re-users, among others. Worst still, many of these informal workers who are too poor to afford a house for themselves live on the dumpsite or at best, in public institutions around the dumpsites. For instance, (Aderibigbe, 2010) reports that: "miscreants and scrap scavengers who ply their trade at the 'TLS colony' (i.e. Olusosun Dumpsite Transfer Loading Station) thronged into the school. It has practically become for them, a home. These boys practically sleep in the school. They have turned the classrooms into their bedrooms and they do all manners of things in here. Our toilets have been taken over by these people and early in the morning between 5.00 am and 6.00 am, you see them leaving the premises and going back to the dumpsite to resume the day's job". In addition to the homeless living on the dumpsites or public institutions around them, there are others who own or hire residential apartment around dumpsites. Thus, the waste dump, especially the big ones like the one in Olusosun, are usually busy with activities of waste picking, 
waste dumping, waste sorting among others, in spite of the environmental filth that pervades the surroundings. The two dumpsites surveyed are not different from the general description detailed above.

Table 1 reveals some of the characteristics of respondents with respect to the relative distances of their residence to the dumpsites. Three classifications are adopted to identify residential locations: those living close to the dumpsite ( 0 to $<$ 250 metres, henceforth referred to as LOC1), those living relatively far away from the dumpsite (500 to $\leq 750$ metres), henceforth referred to as LOC3) and those living in between the two extremes ( 250 to $<500$ metres), henceforth referred to as LOC2). Distributed by households, thirty-four households representing $47 \%$ of the total live in LOC1, 26 which is $36 \%$ of the total responding households live in LOC2 while the remaining households (17\%) live LOC3. Analysis of individual respondents show that 99 respondent which represent $51 \%$ live close to the dumpsite in LOC1, $26 \%$ made of 51 respondents live in-between in LOC2, while the remaining $23 \%$ live farther from the site in LOC3. Among those living close to the dump, $47 \%$ are male while the remaining $56 \%$ are females.

Given the amount of environmental pollution generated by the dumpsite which is clearly obvious to every observer and passerby in terms of obnoxious odour oozing from the dumpsite, the regular discharge of effluents into the atmosphere as a result of incineration activities on the dumpsite, the very dirty and unkempt environments, among many other characteristics of the area, there is little doubt that living in the dumpsite has several health implications. Thus the respondents were asked to state the health effects of living around the dumpsite. Sixty-one percent of the respondents (61\%) confirmed that the environmental pollution from the dumpsite has negative effects on their health status. The reported negative impact is heaviest among those in LOC1 $(57 \%)$ while, as expected, it is least among those in LOC3 (11\%). Many of the respondents reported that the dumpsite-generated pollution makes them suffer different types of ailments such as constant bouts of malaria as a result of infection from mosquitoes' bites; chest-related ailments resulting from inhalation of fumes from waste incineration; as well as all kinds of skin and body irritations. Malaria topped the list of sickness suffered (57\%), followed by skin and other forms of irritations $(19 \%)$ while the least is chest-related problems $(10 \%)$.

The percentage of respondents reporting a particular kind of ailment varies inversely with the distance between the dumpsite and place of residence. Thus, residents of LOC1 are mostly affected compared to those in LOC2 and LOC3 respectively. For instance, while $49.5 \%$ of the respondents in LOC1 are affected by malaria, only $22 \%$ and $28 \%$ experience such ailments in LOC2 and LOC3 respectively. Similar pattern is observed for other types of ailments reported. The pattern of frequency of sicknesses is also similar to the pattern observed with respect to the incidence of ailments. Seventy-one percent of those living closest to the dump (LOC1) have experienced sickness always while only $12 \%$ of those living relatively very far (LOC3) have similar experience. The relative strength of association between the variables examined and the distances of residential houses to the dumpsite is shown in the last column of Table 3 . These are found to be statistically significant at $5 \%$ level or better for all but variables TYP and EMP.

The foregoing analysis thus shows that the dumpsite is one of the major causes of pollution, which in turn can be linked to the state of health of respondents in this study. In addition to the dumpsite, there are other pollution sources in the area. Some of these are pollutions caused by auto vehicles, method of refuse disposal that litters the environment as well as well as the existence of the local/community markets in the area which are major sources of solid waste generation to the environment. The extent of air and water pollution is worse in the raining season as a result of offensive and disease-carrying odour, as well as ground water pollution. In the dry season, smoke from the incineration of the dumpsite is an important source of air pollution. Table 3 and Table 4 show the regression results from both the linear probability model and the ordinary Least Squares regression models respectively. The purpose of the regression exercise is to determine, in a statistical sense, those factors that determine the health status of respondents living around dumpsites.

In Table 4, we reported the results of the two regression estimates tagged Regression 1 and Regression 2. The regression estimates show that four variables (Burning, Self-employed, House location and Health Expenditures) are statistically significant in their influence on health status. For instance, the result in the table shows that air pollution variables (proxied by 'Burning' and 'Odor') vary positively with the probability of being ill. In relation to the distance of residential apartment to the dumpsite, the result shows a negative relationship between state of health (sickness) and home distance to the dumpsite. That is, those living close to the dumpsite suffer more health problems than those living farther from it. This results support the one described in Table 1. We are however surprised that the 'odor' variable is not statistically significant in its effect on health status. Table 3 gives similar result to the one reported in Table 2. For instance, the result shows that BRN and ODR are positive on their effect on being sick, but while BRN is statistically significant at the $5 \%$ level, ODR is not significantly different from zero. The distance variable (LOC) is negatively related to the level of ill-health which means that health situation worsens as distance from dump site to respondents' residence reduces and vice versa. The nature of employment variable 
(EMPTN) is a binary variable measured as 1 if self-employed and zero otherwise. Thus, the negative statistically significant result means that the self-employed have worse state of health compared to the wage employed who are treated as the reference category. In other words, those that are in wage employment are less sickly in comparison to those in self-employment. This result appears plausible for several reasons. First, the wage employees earn more than the self-employed. For instance, while the self-employed has an average monthly income of N27,000 per month ( $\mathrm{N} 150=\mathrm{US} \$ 1)$ those in the wage employment category earn an average of N31,000 per month. Second, those in wage employment are likely to be working outside their area of residence thereby limiting their exposure to environmental pollution to non-work periods. Third, the formal educational attainment of those in wage employment is slightly higher than those in self-employment. Therefore, the combination of improved formal education and higher earning in wage employment are expected to make the wage workers afford better nutrition and curative as well preventive health care for self and family members.

\subsubsection{Environmental Pollution and Labour Market Implications for Respondents}

The foregoing section has shown, in a statistically significant sense, the negative impact of environmental pollution on the state of health of persons living around dumpsites. The issue addressed in this section relates to the labour market implications of waste dump pollution on the environment. It examines the implications of environmental pollution arising from residing around the dumpsite in relation to the health status of residents and the effects it has on the labour market performance of such individuals. The Pearson correlation coefficient between pairs of some selected proxy variables of pollution and labour market outcomes show some interesting results. Using the two-tailed test, the result in Table 5, shows that the frequency of illness is positively correlated (in a statistically significant sense) with being affected by both odour from dumpsite and smoke arising from incineration activities of the dumpsite. Income from employment is significantly negatively correlated with pollution variables of odour and burning. As expected, monthly earnings is negatively related to frequency of illness and self-employment, but is positively related to owning a house as well as the distance of residential accommodation to the pollution source the dumpsite. Being affected by pollution (via odour and burning) is negatively related to the distance of residential homes from the dumpsite. In other words the farther the residential house is from the dumpsite, the lower is the rate of being affected by smoke as well as offensive and disease-carrying odour from dumpsites.

An important labour market variable which is given further attention in this study is the level of earnings and the factors that affect its distribution among respondents. Given the result of the bivariate correlation analysis explained above, a linear regression analysis, shown in Table 4 was specified and estimated. In general, a linear regression gives the coefficient estimates of specified explanatory variables that best predict the value of the dependent variable. In this case, the dependent variable is the Log of earnings while the explanatory variables are the pollution variables (Burning, Odour, LOC1, LOC2, LOC3), labour market variables (Level of education, nature of employmentwhether wage- or self-employment, and labour market experience proxied by age), Size of the household, status in the household (whether head or non-head), among others.

The regression analysis shows that in addition to the labour market variables, environmental pollution variables are also statistically significant determinants of earnings distribution among the survey respondents. In specific terms, being exposed to odour reduces earnings compared to the control group of those that are not. Though not statistically significant, frequency of illness is negatively related to monthly earnings while those that live close to the dumpsite earn less than those living from those relatively far from it. The latter appears plausible as those living closer to the dumpsite are prone to more frequent sicknesses which reduce the amount of time available for productive labour market activities. The sign of the 'Burning' variable does not conform to apriori expectation even though the coefficient is statistically significant at $10 \%$ level. Could it be that the majority of the respondents are engaged in activities that are involved with burning, say, waste iron or plastic smelting? Or, could it be that some of the respondents become familiar with the smoke from incineration over time and their immune system get adjusted to it so that it no longer affects their health and income? For the former, we have no information in the data base to make further comment. However, for the latter, a further analysis of data shows that the proportion of persons that are affected by smoke from burning decreases with their length of stay in the dumpsite area. Also, the Pearson correlation coefficient between length of stay in the dumpsite area and 'Burning' shows a result of -0.136 with a t-values of 0.057 (Table 5). Like the 'burning' variable, the education variable is statistically significant at $5 \%$ level but its sign is contrary to apriori expectation. This may not be unconnected with high level of unemployment among educated graduates who may have been compelled to seek residence around the waste dumpsites and probably be informally engaged in waste-related occupation. This aspect of the finding, among others, is a pointer to the need for further research in this area of study.

\section{Summary of Findings and Concluding Remarks}

This study examined the health status of households living around the Olusosun and Oke-Afa waste dumpsites in Lagos Nigeria. Results from the analysis of data reveals evidence of self-reported illnesses, which is linked with 
pollution from the dumpsite around which they live. Distance between the dumpsite and residential apartment varies inversely with frequency and type of illness reported while the latter affects labour market performance of respondents as shown by the income distribution analysis. For improved health status of the populace and for better labour market performance, a resettlement programme for persons living within 250 metres radius programme is a must for the government. In the long term, efforts to provide low-cost houses situated in a clean environment is a priority that the government must pursue vigorously to enable the poor to live in affordable yet clean environment. To curtail the menace of high rate of rural-urban migration which is an important source of urban congestion and slum, a policy of integrated development whereby the rural sector is developed to provide jobs and social amenities should be made a priority.

\section{References}

Aatamila, M., Verkasalo P., Korhonen M. J., Viluksela M. K., Pasanen K.,Tittanen P., \& A. Vevalainen. (2010). Odor Annoyance Near waste Treatment Centres: A population-based study in Finland. Journal of Air and Waste Management Association, Vol. 60, pp. 412-418. http://dx.doi.org/10.3155/1047-3289.60.4.412

Abul, Salam. (2010). Environmental and Health Impact of Solid Waste Disposal a Mangwaneni Dumpsite in Manzini: Swaziland. Journal of Sustainable Development in Africa, Volume 12, No. 7, pp.64-78.

Aderibigbe, Y. (2010). Ugly Side of the Olusosun Scarvengers. The Nation Newspaper, June 14

Aluko, O. O., \& M. K. C. Sridhar. (2005). Applications of constructed wetlands to the treatment of Leachates from a Municipal Solid Waste Landfills in Ibadan, Nigeria. Journal of Environmental Health, Vol. 67, No. 10; pp 58-62.

Apata, O. (2011). Oke-Afa Canals: More Risks for Residents. Daily Independence, July 13.

Babatunde, M. Adetunji, \& M. Ilias Biala. (2010). Externality Effects of Sachet Water Consumption and the Choice of Policy Instruments in Nigeria: Evidence from Kwara State. Kamla-Raj, Journal of Economics.

Becker, G. S. (1975). Human Capital. Columbia University Press, New York.

Birdsall N., Ross D., \& Richard Sabot. (1995). Inequality and Growth Reconsidered: Lessons from East Asia. The World Bank Economic Review, September.

Boardi K. Owusu, \& Markku Kuitunen. (2005). Environmental and Health Impacts of Household Solid Waste Handling and Disposal Practices in the Third World Cities: The Case of Accra Metropolitan Area, Ghana. Journal of Environmental Health, Vol. 68, No. 4, pp. 34-36.

Environmental Research Foundation. (2011). The Basics of Landfills: How They are Constructed and Why They Fail. Downloaded from http://www.zerowasteamerica.org/BasicsOfLandfills.htm. Retrieved: August 31, 2011.

Goldman G., \& A. Ogishi. (2001). The Economic Impact of Waste Disposal and Diversion in California: A Report to the California Integrated Waste Management Board, University of California.

Gouveia N., \& R. Ruscitto do Prado. (2010). Health Risks in Areas Close to Urban Solid Waste Landfill Sites. Rev Saude Publica, Vol. 44; No. 5; pp.1-8.

Grossman, G., \& A. Krueger. (1995). Economic Growth and the Environment. Quarterly Journal of Economics, Vol. 110, pp 353-377. http://dx.doi.org/10.2307/2118443

Grossman, M. (1972). The Demand for Health: A Theoretical and Empirical Investigation (Columbia University Press for the National Bureau of Economic Research, New York).

IBRD. (1992). World Development Report 1992: Development and the Environment, Oxford University Press, New York.

IBRD. (1999). What a Waste? Solid waste Management in Asia. The International Bank for Reconstruction and Development/THE WORLD BANK 1818 H Street, U.S.A.

Kaldor, Nicholas. (1978). Capital Accumulation and Growth. In Nicholas Kaldor, (Ed)., Further Essays on Economic Theory. New York: Holmes and Meier Publishers, Inc.

Kuznets, Simon. (1955). Economic Growth and Income Inequality. American Economic Review. Vol 45, 1-28.

Lewis, Arthur. (1954). Economic Development with Unlimited Supply of Labour, The Manchester School. Downloaded from http://www.uni-leipzig.de $\sim$ soZio/mitarbeiter/m72/content/dokumente/568/Lewis1954.pdf, retrieved on September 5, 2011.

Mincer, J. (1974). Schooling, Experience and Earnings, Columbia University Press, New York.

Nabegu, A. B. (2010). An Analysis of Municipal Solid Waste in Kano Metropolis. Journal of Human Ecology, Vol. 31, No. 2, pp. 111-119. 
Nwanta, J. E, Onunkwo, J., \& E. Ezenduka. (2010). Analysis of Nsukka Metropolitan Abattoir Solid Waste in south Eastern Nigeria: Public Health Implications. Archives of environmental and Occupational Health. Vol. 65, No.1, pp. 21-26. http://dx.doi.org/10.1080/19338240903390263

Pedrick, A. M. (2001). The Health Production Function: The health Effect of Socio-Economic Variables on an individual's health status. Unpublished B.A. Project Report submitted to the Department of Economics, Union College, Schenectady, New York.

Sarkhel, Prasenjit. (2006). Economics of the Household Waste Management in Kolkata: Proposed Steps towards Improved Efficiency: Contemporary Issues in Social Sciences, March. pp 1-19.

Stern, David. (2003). The Rise and Fall of the Environmental Kuznets Curve. Rensselaer Working Paper in Economics, Number 0302, October.

Stern, D. I., Common, M. S., \& E. B. Barbier. (1996). Economic Growth and Environmental Degradation: The Environmental Kuznets Curve and Sustainable Development. World Development, Vol. 24, pp. 1151-60. http://dx.doi.org/10.1016/0305-750X(96)00032-0

Stern, D. I. (1998). Progress on the Environmental Kuznets Curve? Environment and Development Economics. Vol. 3, pp. 173-196. http://dx.doi.org/10.1017/S1355770X98000102
UN-Habitat.
(2010).
The
State
of
African
Cities,
2010.

http://www.unhabitat.org/documents/SOAC10?SOAC-PRI-en.pdf; retrieved on August, 31, 2011.

UNEP. (undated). Environmental Pollution and Impacts on Public Health: Implications of the Dandora Municipal Dumping Site in Nairobi, Kenya: United Nations Environmental Programme, Nairobi, Kenya

Yahaya, O., Umoh V. J., \& J. B. Ameh. (2011). Public Health Implications of Using Water from Wells Located Near Mnicipal Waste Dump Sites in Parts of Zaria. Medical Practice and Review, 2(4), 44-49.

Yongsi, H. B. N., Hermann, T. M., Ntetu, A. L. Sietchiping R., \& C. Bryant. (2008). Environmental Sanitation and Health Riskes in Tropical Urban Settings: Case Study of Household Refuse and Diarrhea in Yaounde-Cameroon. International Journal of Human and Social Sciences. 3(3), 220-228.

Table 1. Distribution of Some Variables by Location of Respondents' Homes from The Dumpsite and by Other Seclected Variables

\begin{tabular}{|c|c|c|c|c|c|c|c|c|c|c|}
\hline \multirow[t]{2}{*}{ Main Variable } & \multirow[t]{2}{*}{$\begin{array}{l}\text { Derived } \\
\text { Variable }\end{array}$} & \multicolumn{2}{|c|}{$\begin{array}{l}\text { Very Close: } \\
(0-250 \mathrm{~m} .)\end{array}$} & \multicolumn{2}{|c|}{$\begin{array}{l}\text { In-Between: } \\
250-500 \mathrm{~m}\end{array}$} & \multicolumn{2}{|c|}{$\begin{array}{l}\text { Far Away: (> } \\
500 \mathrm{~m})\end{array}$} & \multicolumn{2}{|c|}{ Total } & \multirow[t]{2}{*}{ Chi-Square Test } \\
\hline & & No. & $\%$ & No. & $\%$ & No. & $\%$ & No. & $\%$ & \\
\hline \multirow{3}{*}{ Affected by Odour? } & Yes & 67 & 57 & 38 & 32 & 13 & 11 & 118 & 61 & \multirow{3}{*}{$\begin{array}{l}\text { Value: } 22.91 \\
\text { d.f.: } 2 \\
\text { Sig.: } 0.000\end{array}$} \\
\hline & $\mathrm{N}$ & 32 & 43 & 13 & 17 & 30 & 40 & 75 & 39 & \\
\hline & Total & 99 & 51 & 51 & 26 & 43 & 22 & 193 & 100 & \\
\hline \multirow{3}{*}{$\begin{array}{l}\text { Affected by smoke from } \\
\text { burning? }\end{array}$} & Yes & 62 & 57.9 & 32 & 39.9 & 13 & 12.1 & 107 & 55.4 & \multirow{3}{*}{$\begin{array}{l}\text { Value: } 14.231 \\
\text { d.f. } 2 \\
\text { Sig. } 0.001\end{array}$} \\
\hline & No & 37 & 43 & 19 & 22.1 & 30 & 34.9 & 86 & 44.6 & \\
\hline & Total & 99 & 51.3 & 51 & 26.4 & 43 & 22.3 & 193 & 100 & \\
\hline \multirow[t]{3}{*}{ Length of Residency } & $<1$ Year & 15 & 45 & 14 & 43 & 4 & 12 & 33 & 17 & \multirow{6}{*}{$\begin{array}{l}\text { Value: } 25.43 \\
\text { d.f. } 10 \\
\text { Sig. } 0.005\end{array}$} \\
\hline & $1-5$ Years & 49 & 54 & 24 & 27 & 17 & 19 & 90 & 47 & \\
\hline & 6 Yrs\& over & 35 & 50 & 13 & 19 & 22 & 31 & 79 & 36 & \\
\hline \multirow[t]{3}{*}{ Frequency of Falling ill } & Always & 17 & 71 & 2 & 8 & 5 & 21 & 24 & 12 & \\
\hline & Sometimes & 46 & 51 & 30 & 33 & 14 & 16 & 90 & 47 & \\
\hline & Rarely & 36 & 46 & 19 & 24 & 24 & 30 & 79 & 41 & \\
\hline \multirow{5}{*}{$\begin{array}{l}\text { Type of sickness } \\
\text { suffered }\end{array}$} & Malaria & 53 & 49.5 & 24 & 22.4 & 30 & 28.1 & 107 & 56.9 & \multirow{5}{*}{$\begin{array}{l}\text { Value: } 9.786 \\
\text { d.f. } 6 \\
\text { Sig. } 0.134\end{array}$} \\
\hline & Chest-related & 11 & 57.9 & 4 & 21.1 & 4 & 19 & 19 & 10.1 & \\
\hline & Stomach-related & 14 & 53.8 & 11 & 42.3 & 1 & 3.8 & 26 & 13.8 & \\
\hline & Irritation & 16 & 44.6 & 12 & 33.3 & 8 & 22.2 & 36 & 19.1 & \\
\hline & Total & 94 & 50 & 51 & 27.1 & 43 & 22.9 & 188 & 100 & \\
\hline \multirow[t]{2}{*}{ Employment Status } & Employed & 72 & 52.6 & 37 & 27 & 28 & 20.4 & 137 & 71.7 & \multirow{2}{*}{$\begin{array}{l}\text { Value: } 1.321 \\
\text { d.f. } 2 \text {; Sig. }=0.51\end{array}$} \\
\hline & Unemployd & 27 & 50 & 12 & 22.2 & 15 & 27.8 & 54 & 28.3 & \\
\hline \multirow[t]{2}{*}{ House Ownership } & Yes & 16 & 47.1 & 3 & 8.8 & 15 & 44.1 & 34 & 18.3 & \multirow{2}{*}{$\begin{array}{l}\text { Value: } 14.947 \\
\text { d.f. }=2 ; \text { Sig. }=.001\end{array}$} \\
\hline & No & 21 & 53.3 & 46 & 30.3 & 25 & 16.4 & 152 & 81.7 & \\
\hline
\end{tabular}

Source: Computed by authors from Survey Data 
Table 2. Linear Probability Model Showing the Determinants of Health Status

Dependent Variable: State of Well-Being: (Always/Sometimes Ill=1; Rarely/Never Ill=0)

\begin{tabular}{|c|c|c|c|c|c|c|}
\hline & \multicolumn{3}{|c|}{ REGRESSION 1} & \multicolumn{3}{|c|}{ REGRESSION 2} \\
\hline Variables & Coefficient Estimate & t-Statistic & Sig. & Coefficient Estimate & $\mathrm{t}$-Statistic & Sig. \\
\hline Burning & $0.689 *$ & 2.922 & 0.007 & $0.675^{* * *}$ & 2.804 & 0.10 \\
\hline Odour & -0.204 & -0.864 & 0.395 & -0.191 & -0.792 & 0.436 \\
\hline Home Distance & $-0.001 * * *$ & -2.005 & 0.055 & $-0.001 * * *$ & -1.989 & 0.058 \\
\hline Self-Employed & -0.230 & -2.088 & 0.047 & -0.202 & -1.624 & 0.117 \\
\hline Monthly Earnings & 0.002 & 0.026 & 0.979 & -0.002 & -0.024 & 0.981 \\
\hline Monthly Health Exp. & $-2.3 \mathrm{E}-005^{* *}$ & -2.304 & 0.029 & $-2.2 \mathrm{E}-005^{* *}$ & -2.163 & 0.040 \\
\hline Own House & $-0.261 * * *$ & -1.950 & 0.062 & $-0.281 * *$ & -1.989 & 0.058 \\
\hline Male HH Head & -0.123 & -0.572 & 0.573 & 0.093 & 0.409 & 0.636 \\
\hline Married & 0.080 & 0.488 & 0.630 & 0.096 & 0.565 & 0.577 \\
\hline No. of Children & 0.046 & 0.974 & 0.339 & 0.056 & 1.071 & 0.294 \\
\hline No. in the Household & 0.008 & 0.858 & 0.399 & 0.010 & 0.981 & 0.336 \\
\hline Education of $\mathrm{HH}$ head & & & & 0.038 & 0.513 & 0.612 \\
\hline CONSTANT & 0.626 & 1.331 & 0.195 & 0.218 & 0.428 & 0.673 \\
\hline $\mathrm{R}^{2}$ & \multicolumn{3}{|c|}{0.779} & \multicolumn{3}{|c|}{0.781} \\
\hline Adj. $R^{2}$ & \multicolumn{3}{|c|}{0.685} & \multicolumn{3}{|c|}{0.676} \\
\hline F-Statistic & \multicolumn{3}{|c|}{8.312} & \multicolumn{3}{|c|}{7.425} \\
\hline Sig. of F-Statistic & \multicolumn{3}{|c|}{0.000} & \multicolumn{3}{|c|}{0.000} \\
\hline
\end{tabular}

$*=$ Significant at $1 \%$

$* *=$ Significant at $5 \%$

$* * *=$ Significant at $10 \%$

Source: Computed by the authors from survey data 
Table 3. OLS Regression Result

Dependent Variable: State of Sickness: $($ Always=3. Sometimes $=2$, Rarely $=1$; Never $=0$ )

\begin{tabular}{|c|c|c|c|}
\hline Variables & Coefficients & t-Statistic & Sig. \\
\hline Burning (BRN) & $1.319 *$ & 3.146 & 0.004 \\
\hline Odour (ODR) & -0.685 & -1.629 & 0.115 \\
\hline Home Distance (LOC) & $-0.002 *$ & -2.978 & 0.006 \\
\hline Self-Employed (EMPN) & $-0.406 * *$ & -2.076 & 0.048 \\
\hline Monthly Earnings (EARN) & 0.221 & 1.494 & 0.147 \\
\hline Monthly Health Exp. (HEXP) & $-4.1 \mathrm{E}-005 * *$ & -2.284 & 0.031 \\
\hline Own House (OWN) & -0.057 & -0.239 & 0.813 \\
\hline Male HH Head & 0.055 & 0.142 & 0.888 \\
\hline Married & -0.345 & -1.178 & 0.249 \\
\hline No. of Children (NCHILD) & .0 .024 & 0.270 & 0.791 \\
\hline No. in the Household (HHSIZE) & 0.003 & 0.016 & 0.850 \\
\hline Educ. of HH head (HEDUC) & - & - & - \\
\hline CONSTANT & $1.670 * * *$ & 1.978 & 0.056 \\
\hline $\mathrm{R}^{2}$ & \multicolumn{3}{|c|}{0.662} \\
\hline Adj. $R^{2}$ & \multicolumn{3}{|c|}{0.519} \\
\hline F-Statistic & \multicolumn{3}{|c|}{4.626} \\
\hline Sig. of F-Statistic & \multicolumn{3}{|c|}{0.001} \\
\hline
\end{tabular}

$*=$ Significant at $1 \% * *=$ Significant at $5 \% * * *=$ Significant at $10 \%$

Source: Computed by the authors from survey data 
Table 4. Ordinary Regression Analysis Showing the Determinants of Labour Income

Dependent Variable: Log of Monthly Income

\begin{tabular}{|c|c|c|c|c|c|}
\hline & \multicolumn{2}{|c|}{ Unstandardized Coefficients } & \multirow{2}{*}{$\frac{\text { Standardized Coefficients }}{\text { Beta }}$} & \multirow[b]{2}{*}{$\mathrm{t}$} & \multirow[b]{2}{*}{ Sig. } \\
\hline & B & Std. Error & & & \\
\hline (Constant) & $4.696^{*}$ & 0.198 & & 23.711 & 0.000 \\
\hline AGE & $0.142 *$ & 0.042 & 0.591 & 3.362 & 0.002 \\
\hline burning $=1$ & $0.222 * * *$ & 0.132 & 0.462 & 1.687 & 0.098 \\
\hline odor $=1$ & $-0.320 * *$ & 0.132 & -0.632 & -2.431 & 0.019 \\
\hline Freq. of illness (FRIL) & -0.045 & 0.049 & -0.150 & -0.917 & 0.364 \\
\hline selfemployed $=1$ & $-0.118 * * *$ & 0.069 & -0.245 & -1.710 & 0.094 \\
\hline Own house $=1$ & -0.020 & 0.095 & -0.034 & -0.214 & 0.832 \\
\hline male hh head $=1$ & -0.077 & 0.101 & -0.104 & -0.766 & 0.448 \\
\hline Married = 1 & -0.099 & 0.065 & -0.203 & -1.539 & 0.131 \\
\hline No. in $\mathrm{HH}$ & -0.004 & 0.005 & -0.128 & -0.729 & 0.469 \\
\hline EDUCATION & $-0.082 * *$ & 0.038 & -0.288 & -2.142 & 0.038 \\
\hline LOC1 & $-0.153 * * *$ & 0.077 & -0.340 & -1.997 & 0.052 \\
\hline LOC3 & 0.110 & 0.109 & 0.167 & 1.001 & 0.322 \\
\hline $\mathrm{R}^{2}$ & & & 0.372 & & \\
\hline Adj. $R^{2}$ & & & 0.208 & & \\
\hline F-Statistic & & & 2271 & & \\
\hline Sig. of F-Stat. & & & 0.023 & & \\
\hline
\end{tabular}

$*=$ Significant at $1 \%$ Level or better

** $=$ Significant at $5 \%$ Level or better

$* * *=$ Significant at $10 \%$ Level or better

Source: Computed by the authors from survey data 
Table 5. Pearson'S Correlations Coefficient among Pairs of Selected Variables

\begin{tabular}{|c|c|c|c|c|c|c|c|c|}
\hline & $\begin{array}{l}\text { House } \\
\text { location } \\
\text { distance } \\
\text { to dump }\end{array}$ & $\begin{array}{c}\text { Own } \\
\text { home=1, } \\
\text { zero } \\
\text { otherwise }\end{array}$ & $\begin{array}{c}\text { Self-employed }=1, \\
\text { zero otherwise }\end{array}$ & $\begin{array}{c}\text { Burning=1, } \\
\text { zero } \\
\text { otherwise }\end{array}$ & $\begin{array}{c}\text { Odour=1, } \\
\text { zero } \\
\text { otherwise }\end{array}$ & $\begin{array}{c}\text { Frequency } \\
\text { of illness } \\
\text { dummy }\end{array}$ & $\begin{array}{c}\text { Average } \\
\text { MonthlyIncome }\end{array}$ & $\begin{array}{l}\text { Length of } \\
\text { time in } \\
\text { residence } \\
\text { (years) }\end{array}$ \\
\hline \multirow[t]{3}{*}{$\begin{array}{l}\text { House location } \\
\text { distance to dump }\end{array}$} & 1 & $.188(*)$ & -.094 & $-.246(* *)$ & $-.283(* *)$ & -.135 & -.005 & $.160(*)$ \\
\hline & & .010 & .261 & .001 & .000 & .061 & .947 & .026 \\
\hline & 193 & 186 & 144 & 193 & 193 & 193 & 156 & 193 \\
\hline \multirow{3}{*}{$\begin{array}{l}\text { Own home }=1 \text {, } \\
\text { zero otherwise }\end{array}$} & $.188(*)$ & 1 & -.071 & $-.191(* *)$ & $-.189(* *)$ & $-.196(* *)$ & $.226(* *)$ & $.233(* *)$ \\
\hline & .010 & & .400 & .008 & .009 & .007 & .005 & .001 \\
\hline & 186 & 189 & 141 & 189 & 189 & 189 & 153 & 189 \\
\hline \multirow[t]{3}{*}{$\begin{array}{l}\text { Self-employed=1, } \\
\text { zero otherwise }\end{array}$} & -.094 & -.071 & 1 & .008 & -.072 & .097 & -.121 & .000 \\
\hline & .261 & .400 & & .925 & .389 & .245 & .144 & 1.000 \\
\hline & 144 & 141 & 147 & 147 & 147 & 147 & 147 & 147 \\
\hline \multirow[t]{3}{*}{$\begin{array}{l}\text { Burning=1, zero } \\
\text { otherwise }\end{array}$} & $-.246(* *)$ & $-.191(* *)$ & .008 & 1 & $.850(* *)$ & $.552(* *)$ & -.137 & -.136 \\
\hline & .001 & .008 & .925 & & .000 & .000 & .084 & .057 \\
\hline & 193 & 189 & 147 & 198 & 198 & 198 & 159 & 197 \\
\hline \multirow[t]{3}{*}{$\begin{array}{l}\text { Odour=1, zero } \\
\text { otherwise }\end{array}$} & $-.283(* *)$ & $-.189(* *)$ & -.072 & $.850(* *)$ & 1 & $.502(* *)$ & $-.224(* *)$ & -.105 \\
\hline & .000 & .009 & .389 & .000 & & .000 & .004 & .143 \\
\hline & 193 & 189 & 147 & 198 & 198 & 198 & 159 & 197 \\
\hline \multirow[t]{3}{*}{$\begin{array}{l}\text { Frequency of } \\
\text { illness dummy }\end{array}$} & -.135 & $-.196(* *)$ & .097 & $.552(* *)$ & $.502(* *)$ & 1 & $-.181\left(^{*}\right)$ & -.054 \\
\hline & .061 & .007 & .245 & .000 & .000 & & .023 & .452 \\
\hline & 193 & 189 & 147 & 198 & 198 & 198 & 159 & 197 \\
\hline \multirow[t]{3}{*}{$\begin{array}{l}\text { Average Monthly } \\
\text { Income }\end{array}$} & -.005 & $.226(* *)$ & -.121 & -.137 & $-.224(* *)$ & $-.181(*)$ & 1 & .117 \\
\hline & .947 & .005 & .144 & .084 & .004 & .023 & & .143 \\
\hline & 156 & 153 & 147 & 159 & 159 & 159 & 159 & 159 \\
\hline \multirow[t]{3}{*}{$\begin{array}{l}\text { Length of time in } \\
\text { residence (years) }\end{array}$} & $.160(*)$ & $.233(* *)$ & .000 & -.136 & -.105 & -.054 & .117 & 1 \\
\hline & .026 & .001 & 1.000 & .057 & .143 & .452 & .143 & \\
\hline & 193 & 189 & 147 & 197 & 197 & 197 & 159 & 197 \\
\hline
\end{tabular}

* Correlation is significant at the 0.05 level (2-tailed).

** Correlation is significant at the 0.01 level (2-tailed).

Source: Computed by authors from survey data 